\title{
Med-koreografi og med-dramaturgi som diffraksjon
}

\section{Med som metodologisk agent for skapende og forskende prosesser $i$ Baby Body}

\author{
Tone Pernille Østern ${ }^{1 \star}$ og Lise Hovik ${ }^{2}$ \\ ${ }^{1}$ NTNU Norges teknisk-naturvitenskapelige universitet, ${ }^{2} \mathrm{DMMH}$ \\ Dronning Maud Minnes Høyskole for Barnehagelcererutanning
}

\begin{abstract}
Sammendrag
Baby Body var et kunstnerisk forskningsprosjekt som resulterte i en forestilling med samme navn for de aller yngste barna (0-3 år). Fire kunstnere, av dem to kunstner-forskere, var særlig involvert i prosessen med å skape forestillingen: en kreativ leder/koreograf/regissør (forfatter 1, Tone), en danser/koreograf (Live), en musiker/komponist (Luis) og en dramaturg (forfatter 2, Lise). I prosessen jobbet vi aktivt med å la med stå sentralt: å gjøre noe med materialer, å skape med hverandre, å velge virkemidler med de bevegelser som oppstår, å la både mennesker og materialer ha agens i prosessen. Kunnskapsbidraget med artikkelen er å forsøke å forstå med som en metodologisk agent. Både i den kunstneriske forskningsprosessen og i denne artikkelen er følgende forskningsspørsmål veiledende: Hvordan fungerer «med» som metodologisk agent i forskende og skapende prosesser $i$ Baby Body?
\end{abstract}

Nøkkelord: Kunstnerisk forskning; koreografi; dramaturgi; intra-aksjon; diffraktiv analyse

\begin{abstract}
Baby Body was an artistic research project resulting in a toddler performance with the same title. Four artists, two of whom were artists-researchers, were particularly involved in creating the performance: a creative leader/choreographer/director (author 1, Tone), a dancer/choreographer (Live), a musician/ composer (Luis), and a dramaturg (author 2, Lise). In the process, we worked actively with a focus on $c o-$ : to $c o$-work with materials, $c o$-create, $c o$-choose expressions with the movements that arose. In other words, we actively tried to allow both humans and materials to have agency in the process. The contribution of this article is to investigate and understand $c o$ - as a methodological agent. In the artistic research process in the dance studio, as well as in this article, we are guided by the following research question: How does co-function as a methodological agent in the creative research processes in Baby Body?
\end{abstract}

Keywords: Artistic research; choreography; dramaturgy; intra-action; diffractive analysis

Received: May, 2017; Accepted: October, 2017; Published: December, 2017

^Correspondence to:Tone Pernille Østern, NTNU, 7491 Trondheim. Epost: tone.pernille.ostern@ntnu.no

(C)2017 T.P. Østern og L. Hovik. This is an Open Access article distributed under the terms of the Creative Commons Attribution 4.0 International License (http://creativecommons.org/licenses/by/4.0/), allowing third parties to copy and redistribute the material in any medium or format and to remix, transform, and build upon the material for any purpose, even commercially, provided the original work is properly cited and states its license. 


\section{Kontekst og artikkelens struktur}

Baby Body $y^{1}$ var den andre av fem planlagte koreografiske prosesser i et flerårig paraplyprosjekt med tittelen «Koreografi som poetisk, politisk og pedagogisk handling i samtiden ${ }^{2}$. En teaser av forestillingen kan sees her ${ }^{3}$. I de ulike koreografiske prosessene i paraplyprosjektet undersøkes koreografi på ulike måter i hvert prosjekt, som en form for handling som forholder seg til samtiden. I Baby Body sto med som koreografisk handling $\mathrm{i}$ fokus. Dermed forholdt vi oss til vår samtid fordi vi er interesserte $\mathrm{i}$ de verdier det å skape med fører med seg, både i kunst, forskning, læringsprosesser og samfunn. Å skape med krever dialog, samhandling, lytting, tilstedeværelse og åpenhet mot omverdenen - verdier vi setter høyt. I rollen av å være koreograf-forsker og dramaturg-forsker forsøkte vi aktivt å koreografere med og skape dramaturgi med, og virkelig ta med på alvor, for å se hvordan med virket i kunstnerisk prosess og produkt.

Med fokus på med, forflyttes perspektivet vekk fra diskurser basert på subjekt/ objekt-relasjonen og mot de mer usynlige prosessene som foregår i en kunstnerisk produksjon. Preposisjonsordet med peker mot selve samspillet som en produktiv intensitet (Deleuze \& Guattari, 1991; Massumi, 2002) som sanses kroppslig, som oppstår i ulike intra-aksjoner (Barad, 2007) og som får noe til å skje. Vi forsøker i tillegg å bringe teori inn i dette perspektivet; vi leser vår kunstneriske empiri med posthumanistisk vitenskapsfilosofisk teori. Gjennom en forsøksvis diffraktiv analyse (Barad, 2007; Lenz Taguchi, 2012) prøver vi å forstå hvordan denne forskyvningen mot med virker inn produktivt på den koreografisk-dramaturgiske prosessen, både $\mathrm{i}$ den kunstneriske forskningsprosessen på gulvet og nå, etterpå, når vi analyserer prosessen i denne artikkelen.

Artikkelen strukturerer vi gjennom først å posisjonere oss selv som kunstner-forskere i intra-aksjon, inspirert av posthumanistisk teori. Så definerer vi de sentrale teoretiske begrepene i artikkelen: agent, intensitet og diffraksjon. Så gjør vi selve den diffraktive analysen, gjennom fire agentiske snitt (Barad, 2007; Lenz Taguchi, 2012) og diskuterer til slutt analysen samt hvordan med-koreografi og med-dramaturgi kan bidra produktivt til nye tilblivelser.

\section{Kunstner-forskere i intra-aksjon}

Begrepet intra-aksjon er sentralt hos posthumanisten Karen Barad (2007). Med begrepet forsøker hun å uttrykke noe annet enn inter-aksjon, som hun forstår som en relasjon mellom distinkt separate subjekter. Intra-aksjon destabiliserer tanken om det adskilte subjektet og forsøker isteden få fram at mennesker, materialer og diskurser er sammenvevde. Hverken subjektet, diskursene som omgir oss og som produserer oss, eller den materialitet våre kropper består av og som omverdenen består av, er klart og tydelig avgrenset fra hverandre. Mennesker, materie og diskurser veves sammen.

\footnotetext{
${ }^{1}$ Forestillingen ble skapt perioden januar-mars 2017

${ }^{2} \mathrm{Se}$ https://www.dance-company.no/choreography-as-2016-20 (tilgang 11.04.2017)

${ }^{3}$ https://vimeo.com/204766548 (tilgang 10.10.2017)
} 
Den egne kunstner- eller forskerkroppen kan i et slikt perspektiv aldri forstås som avgrenset og adskilt fra de kropper, materialer og kontekster som det kunstneriske forskningsprosjektet utfolder seg i. Kroppen blir transcorporeal, den blander seg med andre kropper og med omgivelsene, og «matter and meaning are mutually articulated» (Lenz Taguchi, 2012, s. 266). Ved hjelp av Deleuze beskriver Lenz Taguchi hvordan forskeren inngår i slike transkorporale prosesser:

... transcorporeal engagement, involving other bodily faculties than the mind, constitutes a rethinking of the very act of thinking that goes beyond the idea of reflexivity and interpretation as inner mental activities in the separate mind of the researcher. (Lenz-Taguchi, 2012, s. 267)

I arbeidet med Baby Body er forfatter 1 og 2 både kunstnere og forskere i en og samme kropp. Vi jobbet aktivt med med i de praktiske, kunstneriske prosessene gjennom å forsøke å ha høy tilstedeværelse i prosessene, lytte, være åpen for det vi sanset kroppslig, legge merke til når vi opplevde flyt, når vi opplevde stopp og motstand, og gjennom å leke, improvisere, diskutere og reflektere sammen med Live og Luis og hverandre. Slik genererte vi kunnskap og jobbet refleksivt og etisk, samtidig som vi medvirket i å ta kunstneriske valg.

For å kunne jobbe med framhever vi altså i denne artikkelen vår egen forskerposisjon som kroppede kunstner-forskere. Vi kan som forskere ikke adskilles fra andre forskningsdeltakere eller selve forskningen som distanserte og observerende utenfor-prosessen-forskere. I vår kunstneriske forskningsprosess er vi sammenvevde med Live, Luis, materialer, rom, lyder, kropper og strukturer, og vi sanser, relaterer, kjenner, opplever, føler, svetter (over det vi ikke forstår) og lytter som forskere i minst like høy grad som vi observerer, analyserer og språkliggjør. Vi er med som kroppede forskere som kunnskaper sammen med prosessen som utfolder seg, og denne sammenvevingen muliggjør vår forståelse av og tenkning rundt prosessene i Baby Body.

\section{Posthumanisme og agentisk realisme: agens, intensitet og diffraksjon}

Kunnskapsteoretisk fletter vi Baby Body inn i posthumanismen og Barads (2007) agentiske realisme. Innenfor posthumanismen destabiliseres tanken om mennesket som adskilt fra og med enestående makt over naturen, materialer, omverdenen og andre mennesker. Mennesket er alltid del av, og interagerer med, andre kropper (human and non-human bodies), natur, strukturer og systemer. I Barads posthumanistiske agentiske realisme smelter epistemologi sammen med ontologi til en onto-epistemologi. Det finnes ikke en tydelig forskjell mellom å bli/være og å vite/kunne (Lenz Taguchi, 2012, s. 43). Læringssituasjoner (slik forskning også er) foregår i en flyt mellom det tenkende og kjennende, det kroppslige-intellektuelle mellom materielle og diskursive aspekter (jf. Lenz-Taguchi, 2012, s. 43). Begrepet «bodymind» brukes både innen posthumanismen og i mange somatiske praksiser som dans, yoga og pilates for å beskrive denne flyten mellom kropp-og-sinn, forstått som ett. Posthumanismen er et vitenskapsfilosofisk ståsted som går forbi oppdelinger mellom 
subjekt/objekt, teori/praksis, intellekt/kropp og diskurs/materialitet (Lenz-Taguchi, 2012). Diskurser og materialitet er sammenflettede.

For å sette dette i kontakt med den sentrale metodologiske agenten i vårt prosjekt - med - så kan man si at alt som skjer i verden, skjer med.Vi er ingenting før vi koples sammen med noe annet, skriver Lenz Taguchi (2012, s. 43): «varje cell är kopplad till en annan». Vi er i stadig transformasjon og tilblivelse sammen med verden (becoming-with-the world). I intra-aksjoner påvirker og endrer ulike agenter hverandre, og ofte er det ikke mulig å vise tydelig hvor grensen mellom dem går (Lenz Taguchi, 2012, s. 25).

\section{Agens og intensitet}

Innenfor perspektivet agentisk realisme har både mennesker og andre ikke-menneskelige materialiteter agens (Lenz Taguchi, 2012, s. 15). Å ha agens handler om å få ting til å skje. En stol har sterk agens i det den får oss til å sitte på den. I Baby Body oppdaget vi at fargene gul, blå og rød fungerte som produktive agenter. De «ville» ikke bli det koreografen hadde tenkt, men inviterte til helt andre og nye ideer. Dette kommer vi tilbake til i den diffraktive analysen.

Agenter er produktive - eller performative - gjennom å skape affekt. Affekt kan forstås som autonome kroppslige prosesser som virker direkte og uavhengig av refleksjon eller språkliggjøring (Massumi, 1995). Det affektive kan ikke forstås som emosjonelle eller følelsesmessige reaksjoner, men mer som virkninger og intensiteter. Brian Massumi understreker at intensiteter kan forstås mer som styrke og varighet enn som kvaliteter. Intensiteten visker ut tolkninger og narrativer, og virker direkte kroppslig: «Intensity is embodied in purely autonomic reactions most directly manifested in the skin - at the surface of the body, at its interface with things.» (Massumi 1995, s. 85). I denne artikkelen framhever vi det produktive ved slike affektive intensiteter og hvordan de får mennesker til å tenke/gjøre/handle.

I Baby Body la vi merke til, eller forsøkte å legge merke til, hvordan ulike agenter skapte intensiteter i oss. Vi forsøkte å lytte til de intensiteter ulike farger, lyder eller andres ideer skapte i oss. Dette kunne være både behagelige og mindre behagelige kroppslige intensiteter, avhengig av hvordan vi klarte å med-koreografere og medskape i tråd med de agenter vi samhandlet med. Det er krevende, men givende, å legge til rette for og åpne seg for å forske med affekter og intensiteter. Det handler som koreograf-forsker og dramaturg-forsker om å gi slipp på kontroll og åpne seg for dialog, det uventede, og om å bejae ulikheter - igjen, verdier i samtiden som vi setter høyt.

\section{Diffraksjon}

Med begrepet diffraksjon forsøker Barad (2007) å vise sammenvevingen mellom det materielle og diskursive, mellom teori og praksis, kropp og kognisjon. Diffraksjon beskriver opprinnelig et fysisk fenomen: Når bølger møter en hindring, sprer bølgene seg på andre og nye måter enn de ellers hadde gjort. Både diffraksjon og det 
forskningsmetodologisk mer kjente begrepet refleksjon er opprinnelig optiske fenomener (Barad, 2007). Refleksjon peker tilbake til det samme - et speil reflekterer for eksempel samme bildet som det opprinnelige bildet. Diffraksjon reflekterer ikke tilbake til seg selv, men peker heller på ulike muligheter og potensial, avhengig av hvordan fenomenet som studeres interagerer med andre agenter. For eksempel når lysbølger må passere gjennom et lite hull, sprer de seg annerledes etterpå enn hvis hullet (hindringen) ikke hadde vært der.

Diffraksjon får bølger til å bryte av fra det vante. Diffraksjonen peker på mulighet for ulikheter. I denne studien forstår vi diffraksjon som at vi i forskningsmaterialet ser etter de ulike muligheter med som metodologisk agent skapte gjennom Baby Body-prosessen.

\section{En bevegelse inn i en intra-aktiv diffraktiv analyse}

Det er vanskelig å si helt hvor og når et kunstprosjekt starter, men det finnes ofte en agentisk impuls som får noe til å skje. Impulsen til Baby Body var kroppslige ideer i form av kinestetiske stemninger, intensiteter, hos koreografen. På det kroppslig-kinestetiske idéplanet, mens Baby Body ennå ikke var satt ut i livet, fantes en fornemmelse av et knippe kommunikative stemninger, en anelse av et vennlig og inviterende rom produsert av dans og musikk, en idé om en koreografisk-dramaturgisk rød tråd, noen sterke farger, en tanke om materialer, et konkret rom å fylle, og fire kunstnere. Det fantes også et tema: kroppen som levd, som umiddelbar og spontan, kommunikasjonen med de yngste barna, samt et ønske om å ha med med som produktiv intensitet gjennom hele prosjektet.

Rent konkret forstår vi en diffraktiv analyse som å gjøre det Lenz Taguchi (2012, s. 25), basert på Barad, kaller agentiske snitt «[...] i det pågående flödet av intra-aktiviteter som oupphörligen pågår». Snittene får ulike agenter til å framtre, med den hensikt å peke på ulikheter og muligheter som produseres. I Baby Body brukte vi med som redskap til å snitte med. Med det mener vi at med ble et ulikhetsskapende stoppunkt, en hindring mot gjentakelse eller repetisjon. Vi forsøkte derfor da, i den
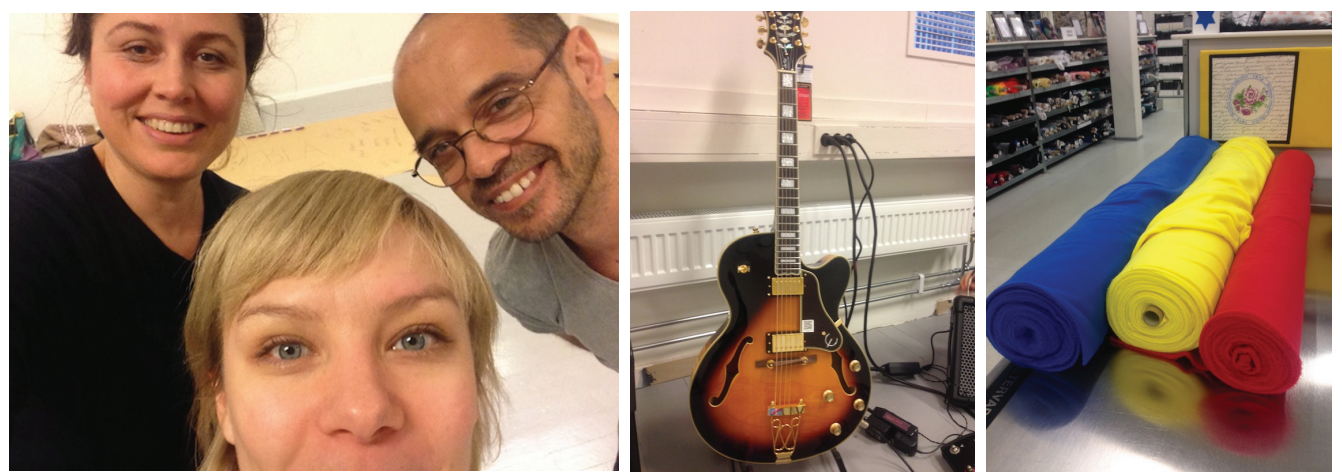

Fotocollage 1. Noen agentiske impulser til Baby Body. 

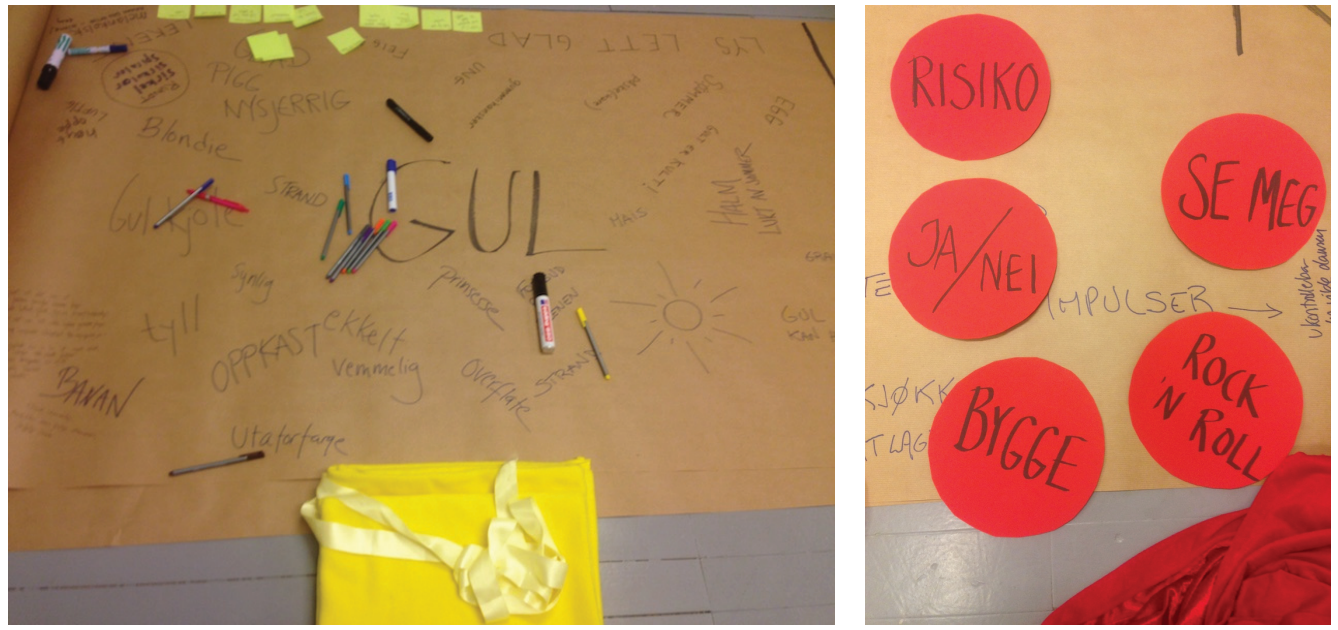

Fotocollage 2. Eksempler på empirisk materiale.

produserende fasen av den kunstneriske prosessen, og nå, mens vi analyserer skriftlig-teoretisk, å se på med som en mulighet for nye tilblivelser. Med tok hele tiden prosessen i nye retninger, men det krevde en aktiv anstrengelse og dedikert vilje fra vår side å gå med med. Ledelse av prosjektet ble distribuert.

Her gjør vi nå noen agentiske snitt gjennom den flyt av pågående intra-aktiviteter som Baby Body-prosessen var. Det empiriske materialet som er produsert undervegs og som vi benytter oss av, er ulikeartet: levde erfaringer, diskusjoner i gruppen som er tatt opp på bånd, individuelle dagbøker der deltakerne skriver ned sine refleksjoner og ulike prosess-produkter som har blitt til undervegs, som kollektive tankekart og improvisasjoner som filmes eller fotograferes.

\section{Farger}

Her gjør vi vårt første agentiske snitt i den diffraktive analysen vi prøver oss på. I dette snittet snitter vi med farger. Fargene i Baby Body fremtrer som agenter som trakk prosessen og forestillingen i en annen retning enn den opprinnelige ideen. Koreografens idé om å bruke tre sekker, en rød, en gul og en blå, var et scenografisk utgangspunkt som åpnet for at materialene kunne virke som agenter, og for at de skulle brukes aktivt i koreografien. Gjennom dette etablerte det seg etter hvert en dramaturgi i forestillingen med tre bilder, scener, eller rom, hvert med sin farge. Den ferdige forestillingen forvandlet seg gjennom de 30 minuttene den varte til det gule rommet, det blå rommet og det røde rommet, alt etter som forestillingen framskred.

I Lives danseimprovisasjoner med sekkene, som etter hvert også fikk ulike stofflige kvaliteter - fleece, silke og fløyel - ble det etter hvert tydelig at sekkene krevde for mye av danseren. De begrenset henne i dansen og ga en type motstand som kunne være interessant $\mathrm{i}$ begynnelsen, men som ble repeterende og anmassende for andre og tredje gang. Danserens bevegelser fikk et arbeidsomt uttrykk, og noe 
av lekenheten ble borte. Det var derfor frigjørende gjennom samtale å bli enige om å legge vekk den røde og gule sekken for å se om det kunne finnes andre muligheter i danserens møte med de andre fargene. Hva om vi forsto fargene som å ha egen agens? Kanskje det røde ikke ville være sekk, men heller en leppestift og en energisk springende bevegelse? Hva ville den gule fargen med Live, Luis, dansen og musikken? Det å skille fargen fra den koreografiske-scenografiske ideen om sekker, gjorde at fargene i seg selv fikk spille på lag, som agenter i intra-aktiviteter. Fargene kunne skape noe annet enn sekk. Danseren skrev i sin dagbok denne dagen:

En viktig avklaring i løpet av dagen var å gå bort fra at vi skulle ha sekker i alle «rommene». Dette kom fram etter tre svake improvisasjoner der jeg følte at sekkene tok for mye plass og ble begrensende.

Koreografen skrev i sin dagbok samme dag:

Jeg syns dagens store forløsning som kom gjennom den dramaturgiske samtalen, var ideen om å kvitte seg med den gule og røde sekken, og kun beholde den blå. Dette var dramaturgens idé. Live tente umiddelbart på den, og jeg forsto at sekkene føltes reduserende. Ideen med å ha sekker var jo opprinnelig at vi skulle ha ting i dem, og hvis vi ikke skulle ha ting i dem, trengte vi kanskje ikke sekkene heller? Etter at dramaturgen hadde gått, snakket vi oss grundig fram til at det gule rommet kunne bestå av at Live hadde på seg gule oppvaskhansker.
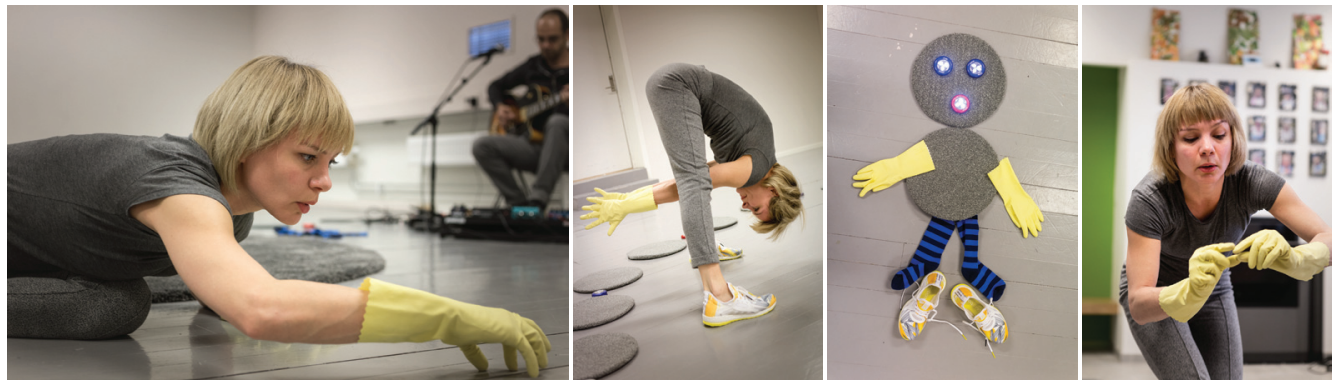

Bildecollage 3. Gul farge med agentskap til å forkaste en gul sekk til fordel for gule oppvaskhansker. Foto: Daniel Almli.

Plutselig hadde den gule fargen skapt noe nytt, fordi vi lot oss gå med fargen. Fargen var produktiv. Gjennom en felles anstrengelse klarte vi å skille fargen fra ideen om sekk, en idé vi hadde hengt oss opp i. En ny Live ble samtidig skapt. Den gule fargen ville at hun skulle danse lett og lekent. De gule oppvaskhanskene inviterte Live inn i en helt ny dans, der hun ble mer seg selv. De gule oppvaskhanskene fikk danseriske ideer til å vikle seg flytende og enkelt uten anstrengelse ut av hennes improvisasjoner. Ut av en slik improvisasjon ble også figuren Baby Body født - med gule hender. Baby Body-figuren ble en fast del av forestillingen. Den gule fargen mante også fram en annen musikk, en rytmisk en, hos Luis. Et gul, lekent, rytmisk rom var skapt, med farge som viktigste agent for å skape diffraksjon, ikke refleksjon tilbake til ideer som ikke fungerte. 


\section{Sangen}

I vårt andre agentiske snitt snitter vi med en del av kroppen: menneskestemmen. Vi snitter med sang. Ved vår første prøveforestilling $i$ en barnehage begynte noen av barna å gråte ved inngangsdøra, før de i det hele tatt hadde kommet inn i rommet til forestillingen. Vi forsto etter hvert at den rytmiske inngangsmusikken som Luis prøvde seg på, ikke skapte trygge nok rammer for de minste. Dette var noe vi forsto på kroppslig vis, vi kjente på det.

Med Luis sin instrumentale tilnærming til musikken, som krevde et lite lydanlegg, en elektrisk gitar og en sampler, var rammen for det musikalske satt. Dramaturgisk la vi opp til at musikken skulle være i rommet når barna ankom rommet, og at stemningen som ble etablert i starten skulle skape trygghet og nysgjerrighet. På denne prøveforestillingen la Luis et enkelt perkusjonstema i det barna skulle komme inn. Ingen av oss voksne oppfattet perkusjonen som skummel, men vi forsto på barnas reaksjon at perkusjonen ga rommet et for mystisk preg. Koreografen skrev i sin dagbok etter denne dagen:

Så var forestillingen i gang. Jeg og Lise satt litt utenfor ringen og så på. Et barn gråt før hun kom inn i rommet, og gråten ble tatt opp på sampleren og dermed hengende i rommet ganske lenge. Starten var litt kaotisk, og Live slet med å fange oppmerksomheten.

Selv om det å spille forestillinger for småbarn i alderen 0-3 år krever høy grad av sensibilitet og nærvær, kan det ukjente og fremmedartede oppleves påtrengende for de minste, og noen vil kanskje uttrykke engstelse. En av barnehagepedagogene sa i sin respons etter prøveforestillingen at musikken var litt skummel for de aller yngste i starten. Etter denne prøveforestillingen hadde vi en lang dramaturgisk samtale, der vi snakket lenge om hva musikken gjør med starten av forestillingen. Vi tok opp hele samtalen på 75 minutter på bånd og har lyttet til den etterpå. Etter at mange ideer var lagt på bordet og forkastet sa dramaturgen til Luis:

- En ting som jeg lurer på, og som jeg vil foreslå, er om du kan synge, i starten. For menneskestemmen, det er det som gjør en baby aller mest trygg. Det er forsket på. Hvis det er en stemme der, så vil det være det elementet som gjør at ting blir greit. Så en rolig, snill, trygg sang, det tror jeg vil fungere.

Tilbake i prøvesalen begynner Luis å eksperimentere med sang. I hans improvisasjoner leter en rolig, nynnende sang uten ord seg fram ${ }^{4}$. Denne sangen videreutvikler han gjennom prøveprosessen og de neste prøveforestillingene, og barna gråter ikke lenger når de kommer inn. Dramaturgisk framstår det som et riktig valg at Luis sitter og synger når barna kommer inn. Her lot vi innsikter om menneskestemmens og sangens beroligende innvirkning spille med i den skapende og forskende prosessen, isteden for å holde fast ved perkusjonen som vi i utgangspunktet, som voksne, likte. Sangen viste seg som en agent som endret hele starten på forestillingen, stemningen, rommet, danserens dans og musikerens musikk. Sangen inviterte barna, isteden for at musikken skremte dem.

${ }^{4}$ Luis Della Mea (C) 2017 https://soundcloud.com/luis-della-mea-delucchi/babybody-intro (tilgang 26.10.2017) 

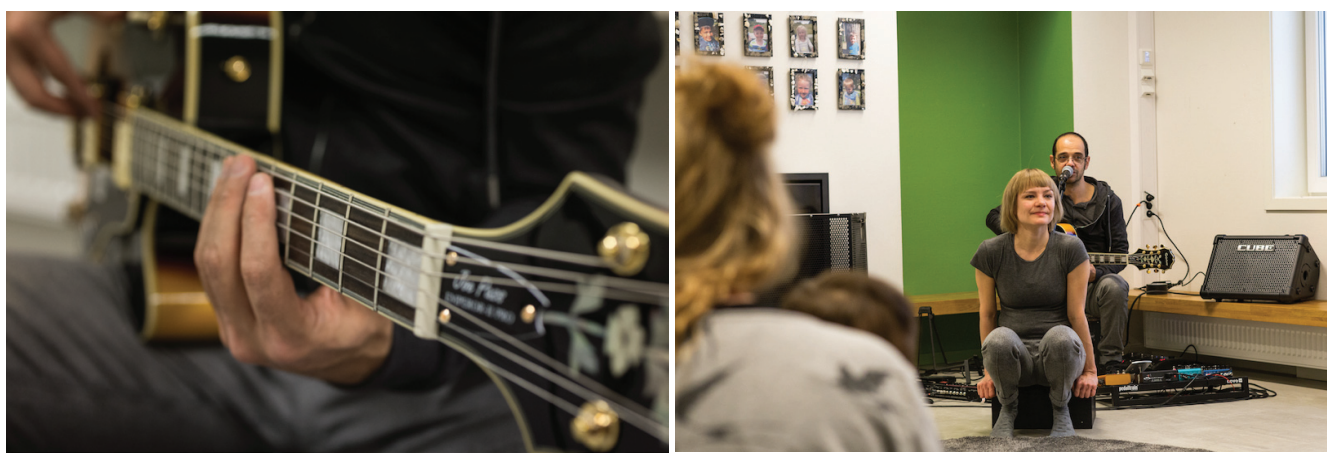

Bildecollage 4. Luis' stemme endrer forestillingen, rommet, stemningen, danseren og barna.

\section{Barna}

Her gjør vi vårt tredje agentiske snitt, og her snitter vi med barna - barnehagens aller yngste, bare 1-3 år gamle.

Når man jobber fram en sceneforestilling, er man (ofte) i en prøvesal og man jobber for seg selv. Man kan lett gå inn i en flyt som blir litt introvert, som mater seg selv innenfra, uten å ta det kommunikative aspektet i betraktning. Allerede etter cirka en uke inn i prosessen kjente koreografen at prosessen trengte å møte barna. De trengte å få virke inn på Luis, Live og hvordan forestillingen skulle bli. Barna ville ha svært tydelig agentskap under visning av forestillingen, og de måtte få virke inn også i prosessen med å skape den. Koreografen skrev i sin dagbok:

Jeg har veldig behov for å treffe barna. Jeg vil veldig at forestillingen skal være for dem, ikke for kunsten i seg. Jeg vil at møtet med forestillingen skal tilføre barna noe positivt, noe de kan forholde seg til, noe de rekker å forstå på sitt vis. Denne lysten til å treffe barna gjorde at jeg ringte til en barnehage på ventelista i dag.

Slik skriver koreografen i sin dagbok etter barnehagebesøket:

Følelser etter denne dagen: Forløsning og betryggelse. Det var utrolig spennende. Jeg satt i ringen hele tiden. Første møtet med publikum. 9 søte 2 -åringer vandret inn, med åpent sinn og gode smil, sammen med 4 barnehagelærere. De hadde umiddelbar og gjennomgripende agentskap. Hele Live og Luis endret seg. Nå ble de kommunikasjon. Kroppene deres, ansiktene deres, holdningen deres åpnet seg. De utstrålte åpenhet.

\section{$[\ldots]$}

Vi satt igjen, og jeg følte at følelsen som preget oss alle var lettelse. En slags betryggelse.Vi la merke til flere ting som måtte jobbes med, men vi gikk fra første møtet med publikum med følelsen at konseptet som sådan fungerer og kan bli en fullverdig forestilling. Vi hadde en lang koreografisk samtale der vi snakket oss gjennom alle aspekter av forestillingen, og la en plan for hva vi måtte endre og jobbe med i morgen. 

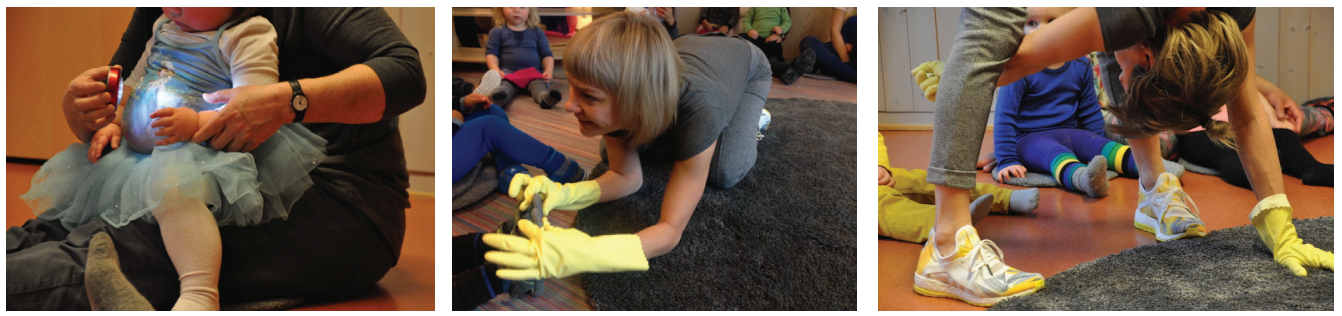

Bildecollage 5. Møte med barna, der barna har sterk agentskap på Live, Luis og forestillingen.

Barna har sterkt agentskap inn i Baby Body-prosessen. I det barna vandrer inn i rommet, skjer det et transcorporealt (Lenz Taguchi, 2012, s. 266) møte mellom utøverne (og koreografen), barna og barnehagepedagogene. Live og Luis veves umiddelbart sammen med barna og barnehagepedagogene; deres tilstedeværelse har også agentskap. Den egne kunstnerkroppen er ikke avgrenset og adskilt fra andre kropper i rommet, men inngår i et nett av kropp, materialer, lyder, forventninger, forhåpninger og kontekster (barnehagen). Barna får Live og Luis til å føle seg tryggere på forestillingen som konsept, og vi får alle en opplevelse av hvordan forestillingen fungerer. Samtidig peker barnas kommunikasjon eller ikke-kommunikasjon med deler av forestillingen umiddelbart på hvor den må endres. Barna har agentskap til å legge en struktur for vårt videre arbeid, og sånn sett lever de med oss resten av perioden.

Med

Det siste agentiske snittet vi gjør, er gjennom selve de med-koreografiske og med-dramaturgiske arbeidsmåtene.

Prøveperioden kommer til en slags slutt i februar, mens vi er i residens på et samfunnshus i Mosvika på Inderøy. Den uken jobber Live og Luis en dag med dramaturgen, og de tar de siste dramaturgiske grepene som får forestillingen til å falle helt på plass. Etter en prøveforestilling på Mosvika barnehage, sitter vi igjen med en følelse av at formen er på plass. Forestillingen er ferdig, og klar til å gå over i en visningsperiode. Den fredag ettermiddagen har koreografen, Luis og Live en lang samtale om den koreografiske prosessen, som vi tar opp på bånd. I løpet av den samtalen blir det helt klart at det er i de periodene av prosessen som er mest åpen og mest tillater at kunstnerne er med, med sine ideer, at de føler at de deltar som kunstnere og får bidra med sitt kunstnerskap. Luis sier:

- Koreografi på den gamle måten å jobbe med, er litt sånn død. Så når vi snakker om koreografi nå, må vi snakke om noe annerledes. For meg er det litt sånn at jeg føler at jeg bidrar mer i starten av prosessen, når den er mer åpen. Det er en idé, som er på gulvet, men det er litt mer åpent, på en måte, og da kjenner jeg at det er en plass for å kaste inn muligheter eller ideer som kan ... mate ideen din. Jeg føler at det er kanskje den første uka ... der var det litt mer plass for å ... fri improvisasjon. Og så tar du en avgjørelse som regissør, og da bidrar vi også, men på en annen måte. Men som kunstner, så føler jeg at jeg bidrar mer i starten av prosessen.

Luis definerer de ulike ukene i prosessen (totalt tre uker), som at den første uken var mest med, en mer leken, kreativ uke; at den andre uken var mer koreografens uke, når hun bestemte mer retning og tok grep, mens den tredje uken var mer å polere 
på en form som begynte å bli ganske fast. Det stemmer også godt med koreografens opplevelser: Hun beskriver sin oppgave slik hun har opplevd det som å kaste inn ideer og impulser som Luis og Live kan skape fritt og åpent rundt under den første fasen, og så $\mathrm{i}$ den neste fasen ta noen valg og bortvalg for å komme videre, og så $\mathrm{i}$ den tredje fasen har hun en mer tilbaketrukken og udefinert rolle. Den tredje uken opplever hun som mer felles, og der det nesten er slik som at forestillingen lever sitt eget liv, som den sterkeste agenten, og mater seg selv. Justeringer og valg kjennes, kroppslig, i fellesskap, og går mer eller mindre av seg selv.

Når det gjelder den følelsesmessige opplevelsen, og opplevelsen av å ha agentskap som kunstner, gjør denne seg helt klart mest gjeldende i den første og siste fasen hos Luis og Live.

Live forteller at et personlig utbytte har vært å være en så stor del av prosessen, og gi hele forestillingen form. Hun sier:

- Jeg føler veldig at det er vår forestilling, og ikke din. Vi har liksom vært med å ta viktige valg. Og det gir et større eierskap til produktet. Som jeg syns er viktig.

Selve arbeidsmåtene og -fasene gjennom Baby Body-prosessen har altså sterk agentskap både på hvordan de ulike menneskelige aktørene oppfører seg i ulike faser (mer eller mindre fritt, mer eller mindre kreativt, mer eller mindre bestemmende), og på hvordan de følelsesmessig har det i de ulike fasene. Det følelsesmessige tangerer etiske aspekter ved prosessen, det å få delta helt og fullt. I de faser av prosessen hvor med er tydeligere til stede, og der det koreografiske og dramaturgiske oppstår fra kollektive situasjoner der det ikke alltid er så lett å spore hvem initiativet kom fra, flyter kreativiteten bedre, følelsen av å bidra med sitt kunstnerskap er større, og eierskapet til det framvoksende produktet er sterkere. Det er krevende å legge til rette for med, men når med er med som arbeidsmåte, fremstår det som en positiv, kreativ, produktiv og etisk ivaretakende intensitet i både kunstner- og forskerkroppene og for de kunstneriske valgene som sådan.

\section{Med som metodologisk agent i Baby Body, koreografi og dramaturgi}

Etter nå å ha gjort fire agentiske snitt gjennom Baby Body-prosessen, vender vi tilbake til forskningsspørsmålet vi stilte oss undervegs i den praktisk-kunstneriske prosessen, og som vi videre har bearbeidet skriftlig-teoretisk i denne artikkelen:

Hvordan fungerer «med» som metodologisk agent i forskende og skapende prosesser $i$ Baby Body?

For å kunne svare på dette, har vi i den diffraktive analysen lest vår empiri med de posthumanistiske begrepene intra-aksjon, agens, intensitet og diffraksjon. Det vi får fram, er hvordan det å få til med, det å gå med ulike agenter som virker inn på prosessen i form av kroppslig kjente intensiteter, krever en aktiv anstrengelse fra oss som koreograf-forsker og dramaturg-forsker. Vi må være villige å gå fra kontroll 


\section{T.P. Østern og L. Hovik.}

til dialog. I dette skjer også en destabilisering av den kontrollen som koreografen og dramaturgen tradisjonelt har (hatt) i sceniske skapende prosesser. Det er ikke det samme å koreografere som å med-koreografere. Det samme gjelder forskerens rolle. Det kreves en aktiv anstrengelse, åpenhet og dedikasjon til å destabilisere forskerens tradisjonelle kontroll (les: makt) over forskningsmaterialet, forskningsdesignen og forskningsspørsmålene, og heller gå mot åpenhet for det som dukker opp undervegs i prosessen og villighet til dialog med mennesker, materialer og strukturer.

De muligheter som en villighet til med åpner opp for, er noe vi kjenner kroppslig $\mathrm{i}$ form av intensiteter. Disse intensitetene kan være behagelige sanse-anelser/ kroppsstemninger (jf. Lenz Taguchi, 2012; Østern, 2013) som kan beskrives som opplevelse av letthet, flyt, glade kriblinger og åpenhet i bryst og pust når det føles som at med-skapingen og med-forskningen fungerer, eller motsatt som ubehagelige sanse-anelser av trykk, lukkethet og motstand når med-prosessene ikke fungerer like godt. Uansett så er det mulighetene ved med som viser seg, som har agens, i form av kroppslig erfarte intensiteter, og som vi som kunstner-forskere har mulighet til aktivt å gå med eller ikke. Bevissthet om disse mellom-kroppslige intensitetene kan lede til forhandling med oss selv om grad av kontroll versus dialog i den skapende og forskende prosessen. Slik sett er det nærliggende for oss å konkludere med at med fungerer som metodologisk agent i skapende og forskende strukturer i den grad vi som kunstner-forskere er bevisste på hvordan vi inngår i transcorporeale sammenhenger, der vi har mulighet til å åpne opp for de potensialiteter (Lenz Taguchi, 2012, s. 115-138) som ligger i med.

Det er også nærliggende å konkludere med at det å skyve fokus vekk fra subjekt/ objekt-relasjonen, og i stedet åpne opp for mellomrommet, der med blir metodologisk agent, er både etisk, kunstnerisk og teoretisk interessant. Med er ikke et ord som kan stå alene, det er et bindeord som binder sammen minst to ting. Dermed åpner med for å sammenflette. I en kunstnerisk prosess gir det å arbeide med ulike agenter positive opplevelser av samspill mellom de medvirkende kunstnerne, i denne studien danseren Live, musikeren Luis, koreograf-forskeren Tone og dramaturg-forskeren Lise. Med får fram opplevelsen av kunstnerisk agens og eierskap gjennom at sammenfletting av ideer og materialer, dialog og deltakelse som verdier i samtiden, framheves. Dette ser vi som verdifullt, både i scenekunst, forskning og samfunn. Dette kan være en måte å forholde oss aktivt til sider ved vår egen samtid som vi setter høyt og ønsker å forsterke, også når vi befinner oss på arenaer som scenekunstproduksjon og forskning.

Vi har i denne artikkelen forsøkt oss på det Barad og Lenz Taguchi kaller en diffraktiv analyse. Med agentiske snitt har vi forsøkt få ulike agenter og det de produserer til å framtre. Vi har i artikkelen valgt å snitte med de agenter som framstår som mest kraftfullt produktive for oss, det vil si fargene, Luis'sang, barna og selve med-arbeidsmåten. Vi kunne også valgt annerledes - vi har lokalisert mange andre agenter som vi spilte på lag med. For selve hensikten med denne artikkelen mener vi 
likevel at det har fungert godt med akkurat disse fire snittene. Vi har kunnet snitte gjennom en skapende og forskende flyt der vi har stoppet opp ved noen agenter (fargene, sangen, barna, arbeidsmåtene) som vi kroppslig har kjent på som produktive intensiteter (jf. Massumi, 1995). Disse agentene har fått noe til å skje fordi vi har åpnet oss mot dem. Å gå med disse agentene har vært produktivt i forhold til å skape kunst, kunnskap, dialog, deltakelse, kunstnerskap, eierskap, tilfredshet i prosessen og til å tenke nye tanker i form av teori som produseres dialogisk i denne artikkelen. Det har også vært produktivt i det at med har krevd av oss som kunstner-forskere å jobbe aktivt med oss selv og de forestillinger om koreografi og dramaturgi vi bærer med oss. Dermed har vi hatt mulighet til å lære, endres og utvikles gjennom den kunstneriske forskningsprosessen.

\section{Avsluttende koreografisk og dramaturgisk perspektivutvidelse}

For helt til slutt å perspektivere prosessene og oppdagelsene vi har beskrevet og undersøkt i denne artikkelen, kan man spørre seg hvorfor vi er interesserte i med i det hele tatt. Svaret er at vi ønsker å delta i det vi oppfatter som en pågående produktiv og kreativ destabiliseringsprosess innenfor et bredt koreografisk og dramaturgisk felt. Det som destabliseres, er maktforholdet mellom hvem som forstås som subjekt og objekt i kunst eller forskning og hvilke stemmer/kropper/materialer/ideer som blir hørt og lyttet til i ulike faser av kunst- eller forskningsproduksjon, samt etiske aspekter. Dette er bevegelser som giør at koreografi og dramaturgi blir noe nytt, noe annet, enn det har vært.

Lenge var dramaturgi i kunstfaglig kontekst dominert av modelltenkning, og av dramaturgi som et teoretisk og tekstorientert fagfelt. Sammen med dramaturgisk praksis i det frie scenekunstfeltet har teoriene beveget seg i en postdramatisk retning, der teksten ikke lenger dominerer, og der produksjonens aktører arbeider mer likestilt og medskapende (Gladsø, Gjervan, Hovik \& Skagen, 2015). Dramaturgen arbeider sammen med de utøvende kunstnerne og er mer en samtalepartner enn den som skal sørge for at fortellingen blir formidlet på den rette måten.

Dramaturgi i vår samtidskontekst, og som vi har forsøkt å forholde oss til gjennom fokus på med i Baby Body, kan vi forstå som en medskapende prosess der kroppslige, materielle, romlige, språklige, lydlige, musikalske og tekstlige bevegelser spiller sammen. Hans-Thies Lehmanns oppgjør med den etablerte dramaturgien i verket Postdramatisches Theater fra 1999/2006 gir en gjennomgang av postdramatiske kjennetegn. Disse omfatter ikke bare en ny måte å forholde seg til tekst, tid og rom på, men også til kroppens tilstedeværelse. I det dramatiske teatret representerer skuespillerens kropp en fiktiv karakter. Dramaet utspiller seg alltid mellom karakterene i stykket, med fokus på å representere den dramatiske situasjonen. Det postdramatiske teatret, derimot, motsetter seg i prinsippet alle former for illusion og representasjon, og skuespilleren vil derfor ikke representere noen andre enn "seg selv». Handlingen skjer $i$ og med den egne kroppen. Kroppen er ikke lenger et medium eller et instrument, men heller en realitet og en utøver av tilstedeværende energi og intensitet. Det er derfor i dans 


\section{T.P. Østern og L. Hovik.}

og danseteater vi oftest finner den nye postdramatiske scenekunstens fokus på det kroppslige tydelig uttrykt. Det handler mer om hva man som kropp kan gjøre, enn hvem man representerer og hvem man er.

Et annet aspekt av en slik postdramatisk destabilisering av kroppen som representativ, er at det kroppslige aspektet kan være med på å gjøre skuespillerkroppen sårbar og personlig, noe som igjen kan henlede publikums oppmerksomhet mot sin rolle som betraktere og vitner i møte med teaterhendelsens her og nå. For det yngste barnepublikummet kan det være en stor hjelp at skuespillerkroppen er nærværende og i god kontakt med seg selv. En representerende funksjon kan virke fremmed og skremmende, men en lyttende og leken tilnærming gir åpning for begge deler. I arbeidet med Baby Body var danseren og musikeren i utgangspunktet seg selv, men begge arbeidet både med og mot den representerende funksjonen utøvere i barneforestillinger gjerne inntar. På et tidspunkt var Live både høne, katt og fugl, men hun valgte å spille det ut mer som en lek med representasjoner, enn som faktiske rollefigurer.

Denne leken kan også forstås som en forskyvning av dramaturgisk fokus fra dramatisk handling og til betydningen av relasjonelle og medskapende faktorer, i dette tilfellet møtet med barna og hvordan de virker inn i den kunstneriske prosessen.

Koreografi er et begrep som lenge har vært i et slags fritt fall, som ikke bindes til samme stabile forankring $\mathrm{i}$ "det å lage dans» som den tradisjonelt har gjort. Vi oppfatter at det foregår en orientering mot koreografi som agent i samfunnet (og ikke bare i støvete kulisser): demokratisering av koreografi, koreografi som kritisk praksis, sammenhengen mellom kropp og språk, artikulering av koreografisk kunnskap og erfaring, samt frigjørelse av koreografi fra dansens etablerte estetikker, og til og med fra dans i det hele tatt. Vi forstår denne frigjøringen fra det etablerte som produktiv destabilisering som får koreografipraksiser og -forståelser til å flytte på seg, endres. Destabiliseringen virker som en intensitet som produserer nye spørsmål. Koreograf og kunstnerisk forsker Per Roar (2016, s. 309) skriver at spørreord som hva, hvordan og hvorfor sammen med begreper som å utforske og undersøke hyppig er blitt brukt på dansekunstfeltet de seneste cirka 10 årene. Spørreordene er samtidig sentrale kunstfagdidaktiske spørsmål. Vi kan dermed forstå hele den pågående destabiliseringen av koreografibegrepet som en slags kritisk koreografididaktisk problematisering av hva, hvordan og hvorfor koreografi, men også når og hvor koreografi (når og hvor forstår vi som nyere kunstfagdidaktiske spørsmål relevante i samtiden), og kanskje mest av alt som en problematisering av hva koreografi gjør og hvordan koreografi virker. Koreograf og forsker Jenn Joy (2015) skriver at koreografi er å engasjere seg. Å engasjere seg koreografisk innebærer å plassere seg i forhold til en eller flere andre og gi impulser, vente, lytte og delta i en dypt dialogisk tilstand av oppmerksomhet. Dette har vi forsøkt gjennom aktivt, og ikke uten anstrengelse, å åpne oss for med som metodologisk agent i Baby Body. Det vi dermed erfarer, er at koreografi som handling og praksis blir demokratisert.

I arbeidet med Baby Body valgte vi ulike dramaturgiske og koreografiske innganger og utganger: på tvers, gjennom og med de kunstneriske prosessene, noe som 
underbygger samtidskunstens syn på dramaturgi som medskapende samtale, koreografi som medskapende bevegelse, og postdramatisk dekonstruksjon av fortelling og rollefigurer. Vår interesse for med som produktiv intensitet og metodologisk agent i prosessen med å skape Baby Body, har bakgrunn i interessen for å delta i en undersøkende, destabiliserende og dermed nyskapende bevegelse av koreografi- og dramaturgibegrepet. Vi håper prosjektet og denne artikkelen kan bidra inn denne pågående nyskapende bevegelsen, i retning med-koreografi og med-dramaturgi.

\section{Forfatteromtaler:}

Tone Pernille Østern, (Dr. of Arts in dance) har doktorgrad fra Teaterhögskolan ved Kunstuniversitetet i Helsinki. Hun er dansekunstner/koreograf på det frie scenekunstfeltet og fra år 2016 professor i kunstfagdidaktikk med vekt på dans ved Institutt for lærerutdanning, NTNU (førsteamanuensis år 2009-16). År 2011 var hun skapende fylkeskunstner i Sør-Trøndelag fylkeskommune. Ved Institutt for lærerutdanning er hun fagseksjonsleder for Kunstfag, kroppsøving og idrett, der hun også er fagansvarlig for mastergraden i kunstfagdidaktikk. Hun har høy aktivitet som kunstner-forsker og veileder kontinuerlig master- og ph.d-studenter. Se https://www.ntnu.no/ansatte/tone.pernille.ostern, https://www.ntnu.no/ilu/200milliarder, https://www.ntnu.no/ ilu/spaceme, www.dance-company.no, www.danselaboratoriet.no

Lise Hovik (ph.d) er dramapedagog og førsteamanuensis i drama ved Dronning Mauds Minne Høgskole for barnehagelærerutdanning, DMMH. Hennes doktoravhandling var en kunstnerisk og teoretisk undersøkelse av barneteatrets interaktive og performative estetikk, med fokus på lek og improvisasjon. Forestillingen De Røde Skoene dannet et kunstnerisk utgangspunkt for forskningsarbeidet. Hovik har skapt en rekke forestillinger for de minste barna som regissør. Hun sitter for tiden i faglig utvalg for scenekunst i Norsk Kulturråd (2016-18), og arbeider med et nytt kunstnerisk forskningsprosjekt rettet mot barnehagebarn, Verken Fugl eller Fisk (2018). Se http://teaterfot.no/

\section{Kreditering kunstnere-forskningsdeltakere:}

Live Strugstad er frilansbasert dansekunstner med BA i samtidsdans fra London Contemporary Dance School. Hun har jobbet som danser, koreograf og dansepedagog fra 2001. Hun har deltatt i mange skapende prosesser for å lage forestillinger for det yngste publikum, og turnert omfattende med forestillingene i både Norge og utenlands.

Luis Della Mea er frilansbasert musiker, komponist og dansekunstner. Med musikk- og danseutdanning fra Buenos Aires har han jobbet som koreograf, danser, musiker og komponist i Norge fra 2003. Baby Body er hans andre babyforestilling som musiker, komponist og utøver.

\section{Referanser}

Barad, K. (2007). Meeting the Universe Halfway. Quantum Physics and the Entanglement of Matter and Meaning. Durham and London: Duke University Press.

Deleuze, G. \& Guattari, F. (1991). Persept, affekt og konsept. I K. Bale \& A. Bø-Rygg (red.), Estetisk teori. En antologi (s. 491-519). Oslo: Universitetsforlaget.

Gladsø, S., Gjervan, E. K., Hovik, L. \& Skagen, A. (red.) (2015). Dramaturgi. Forestillinger om teater. Oslo: Universitetsforlaget.

Joy, J. (2014). The Choreographic. Cambridge, MA og London: The MIT Press.

Lehmann, H.-T. (1999/2006). Postdramatic theatre. London: Routledge.

Lenz Taguchi, H. (2012). Pedagogisk documentation som aktiv agent. Introduktion till intra-aktiv pedagogik. Malmö: Gleerups.

Massumi, B. (1995). The autonomy of affect. Cultural Critique, 31(The Politics of systems and environments, Part II), 83-109.

Massumi, B. (2002). A shock to thought: expression after Deleuze and Guattari. London: Routledge. 


\section{T.P. Østern og L. Hovik.}

Roar, P. (2016). Kunstnerisk forskning og morgendagens dans. Utprøving og refleksjon for utvikling av ny innsikt og praksis. I S. Svendal Øvreås (red.), Bevegelser - Norsk dansekunst $i 20$ år (s. 309-19). Leikanger: Skald forlag.

Østern, T.P. (2013). The Embodied Teaching Moment: the Embodied Character of the Dance Teacher's Practical-pedagogical Knowledge Investigated in Dialogue with Two Contemporary Dance Teachers. Nordic fournal of Dance, Vol. 4 (1) 2013, 28-47.

\section{Digitale referanser:}

Om forskningsprosjektet «Koreografi som poetisk, politisk og pedagogisk handling i samtiden» https://www. dance-company.no/choreography-as-2016-20 (tilgang 11.04.2017)

Teaser Baby Body https://vimeo.com/204766548 (tilgang 10.10.2017)

Lydprøve av Luis Della Mea (C) 2017 https://soundcloud.com/luis-della-mea-delucchi/babybody-intro (tilgang 26.10.2017) 